\title{
Occurrence of some pathogenic microorganisms in kareish cheese and their public health significance
}

\author{
G. M. Hassan ${ }^{1}$, Samia I. Afify ${ }^{2}$ \\ 1 Department of Food Hygiene, Faculty of Veterinary Medicine, Bani-Suef University, Egypt and \\ ${ }^{2}$ Department of Microbiology, Animal health research Institute, Bani-Suef, Egypt.
}

\begin{abstract}
Fifty random samples of Kareish cheese were collected from different localities in Bani-suef Governorate. All samples were examined chemically for acidity, salt and moisture percent and bacteriologicaly for the presence of Escherichia coli, Staphylococcus aureus, Enterococci, Bacillus cereus, Clostridium perfringens, Yersinia enterocolitica, Salmonella and Shigella species. The obtained results revealed that the mean values of acidity, salt and moisture \% were $1.63 \pm 0.095$, $3.55 \pm 0.299$ and $58.54 \pm 0.599$ in the examined kareish cheese samples, respectively.

Escherichia coli, Staphylococcus aureus, Enterococci, Bacillus cereus, Clostridium perfringens were recovered from $16(32 \%), 12(24 \%), 46(92 \%), 25(50 \%)$ and $3(6 \%)$ with a mean value of $4.86 \times 10^{2}$ $\pm 4.21 \times 10^{2}, 4.84 \times 10^{5} \pm 2.91 \times 10^{5}, 3.74 \times 10^{6} \pm 1.55 \times 10^{6}, 7.08 \times 10^{4} \pm 2.61 \times 10^{4}$ and $9.5 \times 10{ }^{1} \pm 7.37 \times 10{ }^{1}$ of the examined samples, respectively. Yersinia enterocolitica could be isolated from $12 \%$ of the examined samples. Salmonella and Shigella species could not be detected in any of the examined samples. The isolated Escherichia coli were examined for serological identification, Enterotoxigenicity and the susceptibility of the isolated serovars to various chemotherapeutic agents. The public health significance and economical importance of the isolated organisms and the recommendations to be followed in the processing, handling and storage of such dairy product were discussed
\end{abstract}

Kareish cheese is a kind of soft cheese which is manufactured from raw buffaloe's and cow's skimmed milk in farmer's houses. The increasing demand for it by the Egyptian consumers is mainly attributed to its high protein content and low price. Raw milk is considered as a good medium for growth of different pathogenic microorganisms. Robinson (1990) showed that the main sources of pathogenic bacteria in cheese are contaminated raw milk, food handlers, dust, utensils and insects. Van Netten et al., (1990) investigated three outbreaks of B. cereus food poisoning in Spain and Netherlands. Wieneke et al., (1993) stated that milk and milk products were the vehicle in $8 \%$ of 359 outbreaks and sporadic cases of staphylococcal food poisoning in the United Kingdom between 1969 and 1990; Djuretic, et al., (1997) mentioned that verocytotoxin producing E.coli was responsible for 3 outbreaks associated with consumption of milk and milk products in England and Wales. Enterococci affects on the microbiological, the physicochemical and the sensory characteristics of cheese as it positively affected the counts of non-starter lactic acid bacteria (NSLAB), micrococci and Coliforms (Sarantinopoulos et al., 2002). The presence of
Clostridium perfringens in dairy products is indicator of faecal or soil contamination and usually associated with spoilage problems as late blowing in cheese Robinson (1990). The aim of the present work was determination of acidity, salt, moisture $\%$ as well as occurrence of some pathogenic bacteria in kareish cheese, studying the Enterotoxigencity and resistance of isolated E.coli strains to some chemotherapeutic agents in vitro and discussion of the public health significance of the isolated organisms.

\section{Material and methods}

Sampling. A total of 50 random samples of kareish cheese were collected in sterile bags from different local markets in Bani-Suef Governorate during spring and summer of 2007 and transported directly to the laboratory in ice box to be examined chemically and bacteriologically.

Chemical examination. The moisture content, sodium chloride and titratable acidity $\%$ of kareish cheese samples were determined according to the methods recommended by A.P.H.A. (1992).

Bcteriological examination. Each sample was thoroughly mashed in a sterile mortar, eleven grams of prepared cheese sample were 
Table (1): Statistical analytical results of chemical examination of the examined kareish cheese samples.

\begin{tabular}{ccccc}
\hline Parameter & $\begin{array}{c}\text { No. of examined } \\
\text { samples }\end{array}$ & Minimum & Maximum & Mean \pm SEM \\
\hline Acidity \% & 50 & 0.300 & 3.63 & $1.63 \pm 0.095$ \\
Salt \% & 50 & 0.293 & 8.78 & $3.55 \pm 0.299$ \\
Moisture \% & 50 & 47.800 & 69.00 & $58.54 \pm 0.599$ \\
\hline
\end{tabular}

Table (2): Statistical analytical results of Escherichia coli , Staphylococcus aureus, Enterococci , Bacillus cereus and Clostridium perfringens counts in the examined kareish cheese samples.

\begin{tabular}{cccccc}
\hline \multirow{2}{*}{ Bacterial counts } & \multicolumn{2}{c}{ Positive } & & & \\
& \multicolumn{2}{c}{ samples } & Minimum & Maximum & Mean \pm SEM \\
\cline { 2 - 3 } & No. & $\mathbf{\%}$ & & & \\
\hline Escherichia coli & 16 & 32 & $<3$ & $2.1 \times 104$ & $4.86 \times 102 \pm 4.21 \times 102$ \\
Staphylococcus aureus & 12 & 24 & $<100$ & $1.1 \times 107$ & $4.84 \times 105 \pm 2.91 \times 105$ \\
Enterococci & 46 & 92 & $<100$ & $5.5 \times 107$ & $3.74 \times 106 \pm 1.55 \times 106$ \\
Bacillus cereus & 25 & 50 & $<100$ & $9.1 \times 105$ & $7.08 \times 104 \pm 2.61 \times 104$ \\
Clostridium perfringens & 3 & 6 & $<100$ & $3.6 \times 103$ & $9.5 \times 101 \pm 7.37 \times 101$ \\
\hline
\end{tabular}

Table (3): Frequency distribution of Escherichia coli (MPN) count/g in the examined kareish cheese samples.

\begin{tabular}{|c|c|c|}
\hline \multirow[t]{2}{*}{ Intervals } & \multicolumn{2}{|c|}{ Escherichia coli (MPN) } \\
\hline & No. of samples & $\%$ \\
\hline$<\mathbf{3}$ & 34 & 68 \\
\hline 3-9 & 4 & 8 \\
\hline $10-<10^{2}$ & 5 & 10 \\
\hline $10^{2}-<10^{3}$ & 5 & 10 \\
\hline $10^{3}-<10^{4}$ & 1 & 2 \\
\hline$\geq 10^{4}$ & 1 & 2 \\
\hline Total & 50 & 100 \\
\hline
\end{tabular}

aseptically homogenized with $99 \mathrm{ml}$ of sterile $2 \%$ sodium citrate solution at $40^{\circ} \mathrm{C}$, serial dilutions of the homogenates were prepared. Isolation and identification of E.coli, Salmonella spp., Shigella spp., Staph. aureus, B. cereus, $C$. perfringens, $Y$. enterocolitica and Enterococci were done according to (A.P.H.A. 1992; Collee et al.,1996).

Serological typing of $E$. coli. Agar slants containing generous growth of E. coli isolates were submitted for agglutination tests using polyvalent and monovalent O E.coli antisera .

Detection of $\boldsymbol{E}$. coli enterotoxin. It was performed according to (Guarino et al., 1987) Swiss albino suckling white mice aged 2-4 days old were used to detect enterotoxigenicity of E. coli. These mice separated from their mothers immediately before use, 22 tested suckling mice were used. Each isolated strain was inoculated into Brain heart infusion broth and incubated at $37^{\circ} \mathrm{C}$ for $18 \mathrm{hrs}$ then centrifuged at 3000 r.p.m. for 20 minutes, The supernatant fluid was filtrated and tested for toxigenic activity by orogastric inoculation of $0.1 \mathrm{ml}$ of supernatant in each of two infant mice. All mice were kept at room temperature for four hours, after which they were anaesthetized with ether, the abdomen was opened and the entire intestine was removed, the weight of the gut and the remaining carcases of two mice were taken, the ratio of the gut weight was calculated for each mouse and the results averaged, the ratio below 0.083 was considered negative while ratio of 0.083 or above was considered positive result for enterotoxigenicty

Susceptibility of E.coli isolates to various chemotherapeutic agents. The disk diffusion technique was adopted according to (Koneman et al.,1992). The following antibiotic discs were used; ceftiofur (30 mg), chloramphenicol (30 $\mathrm{mg})$, lincomycin $(15 \mathrm{mg})$, spectinomycin (200mg), amoxicillin (25 mg), norfloxacin (10 $\mathrm{mg}$ ), neomycin $(30 \mathrm{mg})$, gentamycin (30 $\mathrm{mg})$ and doxycycline $(30 \mathrm{mg})$.

\section{Results and Discussion}


Table (4): Frequency distribution of Staphylococcus aureus, Enterococci, Bacillus cereus and Clostridium perfringens counts/gm (SPC) in the examined kareish cheese samples.

\begin{tabular}{|c|c|c|c|c|c|c|c|c|}
\hline \multirow[t]{2}{*}{ Intervals } & \multicolumn{2}{|c|}{$\begin{array}{c}\text { Staphylococcus } \\
\text { aureus }\end{array}$} & \multicolumn{2}{|c|}{ Enterococci } & \multicolumn{2}{|c|}{ Bacillus cereus } & \multicolumn{2}{|c|}{$\begin{array}{l}\text { Clostridium } \\
\text { perfringens }\end{array}$} \\
\hline & $\begin{array}{c}\text { No. of } \\
\text { samples }\end{array}$ & $\%$ & $\begin{array}{c}\text { No. of } \\
\text { samples }\end{array}$ & $\%$ & $\begin{array}{c}\text { No. of } \\
\text { samples }\end{array}$ & $\%$ & $\begin{array}{c}\text { No. of } \\
\text { samples }\end{array}$ & $\%$ \\
\hline$<10^{2}$ & 38 & 76 & 4 & 8 & 25 & 50 & 47 & 94 \\
\hline $10^{2}-<10^{3}$ & 4 & 8 & 10 & 20 & 4 & 8 & 2 & 4 \\
\hline $10^{3}-<10^{4}$ & 2 & 4 & 9 & 18 & 7 & 14 & 1 & 2 \\
\hline $10^{4}-<10^{5}$ & 2 & 4 & 9 & 18 & 6 & 12 & & \\
\hline $10^{5}-<10^{6}$ & 1 & 2 & 6 & 12 & 8 & 16 & & \\
\hline $10^{6}-<10^{7}$ & 2 & 4 & 7 & 14 & & & & \\
\hline$\geq 10^{7}$ & 1 & 2 & 5 & 10 & & & & \\
\hline Total & 50 & 100 & 50 & 100 & 50 & 100 & 50 & 100 \\
\hline
\end{tabular}

Table (5): Serological identification of Escherichia coli isolated from the examined kareish cheese samples.

\begin{tabular}{ccc}
\hline Escherichia coli serogroups & NO. & \% \\
\hline $\mathbf{O}_{111}$ & 4 & 25 \\
$\mathbf{O}_{\mathbf{8}}$ & 3 & 18.75 \\
$\mathbf{O}_{\mathbf{1 2 5}}$ & 3 & 18.75 \\
$\mathbf{O}_{\mathbf{2 9}}$ & 1 & 6.25 \\
Untypable & 5 & 31.25 \\
\hline
\end{tabular}

Table (6): Enterotoxigenicity of isolated Escherichia coli serogroups from the examined kareish cheese samples.

\begin{tabular}{ccccccc}
\hline \multirow{2}{*}{ Escherichia coli serogroups } & \multicolumn{4}{c}{ Enterotoxigenic activity } \\
\cline { 3 - 7 } & & Negative & \% & Positive & $\%$ \\
\hline $\mathbf{O}_{111}$ & $\mathbf{( 4 )}$ & 1 & 25 & 3 & 75 \\
$\mathbf{O}_{\mathbf{8}}$ & $\mathbf{( 3 )}$ & 1 & 66.67 & 1 & 33.33 \\
$\mathbf{O}_{\mathbf{1 2 5}}$ & $\mathbf{( 3 )}$ & 1 & 33.33 & 2 & 66.67 \\
$\mathbf{O}_{\mathbf{2 9}}$ & $\mathbf{( 1 )}$ & 100 & 0 & 0 \\
\hline
\end{tabular}

Table(7): The susceptibility of isolated Escherichia coli serogroups from the examined kareish cheese samples to various chemotherapeutic agents.

\begin{tabular}{|c|c|c|c|c|c|c|c|c|c|c|c|c|c|c|c|c|}
\hline \multirow{3}{*}{$\begin{array}{c}\text { Chemotherapeutic } \\
\text { agents }\end{array}$} & \multicolumn{4}{|c|}{$\mathbf{O}_{111}$} & \multicolumn{4}{|c|}{$\mathrm{O}_{8}$} & \multicolumn{4}{|c|}{$\mathbf{O}_{125}$} & \multicolumn{4}{|c|}{$\mathbf{O}_{29}$} \\
\hline & \multicolumn{2}{|c|}{$\mathbf{R}$} & \multicolumn{2}{|c|}{$\mathbf{S}$} & \multicolumn{2}{|c|}{$\mathbf{R}$} & \multicolumn{2}{|c|}{$\mathbf{S}$} & \multicolumn{2}{|c|}{$\mathbf{R}$} & \multicolumn{2}{|c|}{$\mathbf{S}$} & \multicolumn{2}{|c|}{$\mathbf{R}$} & \multicolumn{2}{|c|}{$\mathbf{S}$} \\
\hline & No. & $\%$ & No. & $\%$ & No. & $\%$ & No. & $\%$ & No. & $\%$ & No. & $\%$ & No. & $\%$ & No. & $\%$ \\
\hline 1-Ceftiofur & 0 & 0 & 4 & 100 & 0 & 0 & 3 & 100 & 0 & 0 & 3 & 100 & 0 & 0 & 1 & 100 \\
\hline 2-chloramephenicol & 3 & 75 & 1 & 25 & 3 & 100 & 0 & 0 & 2 & 66.67 & 1 & 33.33 & 1 & 100 & 0 & 0 \\
\hline $\begin{array}{l}\text { 3-Lincomycin + } \\
\text { Spectinomycin }\end{array}$ & 0 & 0 & 4 & 100 & 0 & 0 & 3 & 100 & 0 & 0 & 3 & 100 & 0 & 0 & 1 & 100 \\
\hline 4-Amoxicillin & 4 & 100 & 0 & 0 & 1 & 33.33 & 2 & 66.67 & 3 & 100 & 0 & 0 & 0 & 0 & 1 & 100 \\
\hline 5-Norfloxacin & 1 & 25 & 3 & 75 & 0 & 0 & 3 & 100 & 0 & 0 & 3 & 100 & 0 & 0 & 1 & 100 \\
\hline 6-Neomycin & 2 & 50 & 2 & 50 & 2 & 66.67 & 1 & 33.33 & 2 & 66.67 & 1 & 33.33 & 0 & 0 & 1 & 100 \\
\hline 7-Gentamycin & 0 & 0 & 4 & 100 & 1 & 33.33 & 2 & 66.67 & 0 & 0 & 3 & 100 & 0 & 0 & 1 & 100 \\
\hline 8-Doxycycline & 2 & 50 & 2 & 50 & 2 & 66.67 & 1 & 33.33 & 3 & 100 & 0 & 0 & 0 & 0 & 1 & 100 \\
\hline
\end{tabular}


Table (8): Incidence of Yersinia enterocolitica, Salmonella spp. and Shigella spp, in the examined kareish cheese samples.

\begin{tabular}{lccc}
\hline Isolates & No. of examined samples & \multicolumn{2}{c}{ Positive samples } \\
\cline { 3 - 4 } & & No. & $\%$ \\
\hline Yersinia enterocolitica & 50 & 1 & 2 \\
Salmonella & 50 & 0 & 0 \\
Shigella & 50 & 0 & 0 \\
\hline
\end{tabular}

The results in Table (1) revealed that the acidity percentage of the examined kareish cheese samples ranged from $0.3 \%$ to $3.63 \%$ with a mean value of $1.63 \pm 0.095$. Nearly similar results were reported by Mahmoud (1993); Abd El-Shaheed (1996); Khair Allah (2000), comparatively lower results were reported by Saleh(1989); Nawar (2001); Bahout and Moustafa(2006) while higher results were reported by El-Mossalami (1999).

The reported high value of acidity \% may be attributed to the method of kareish cheese manufacture, in which, skimmed milk is placed at warm place for about 24-48 hours giving the chance for lactic acid producing microorganisms to grow and multiply with the production of acid as well as contamination of raw milk by these organisms.

The results in Table (1) indicated that the salt percentage of the examined kareish cheese samples ranged from $0.293 \%$ to $8.78 \%$ with a mean value of $3.55 \pm 0.299$. Nearly similar results were reported by Abd El-Shaheed(1996); Khair Allah (2000); Nawar (2001), while higher results were reported by El-Leboudy (1989); Saleh(1989); Mahmoud (1993); Bahout and Moustafa (2006). Lower values were reported by El-Mossalami (1999) Aly et al., (2007).

Salt is added to kareish cheese to prevent or at least to retard the growth of microorganisms leading to prolongation of the shelf life and permission of suitable acid fermentation.

The results in Table (1) revealed that the moisture content of the examined kareish cheese samples varried from $47.8 \%$ to $69.0 \%$ with a mean value of $58.54 \pm 0.599$.

Nearly similar results were reported by Bahout and Moustafa(2006); Aly, et al.,(2007) .

The wide range of variation in salt $\%$ and moisture content may be attributed to the different sources of samples or the differences in marketing times where the prolonged aging causes declining in the moisture content of the kareish cheese leading to the increase in the sodium chloride concentration .
The results in Table (2) revealed that Escherichia coli was present in $16(32 \%)$ of the samples and Escherichia coli counts (MPN/g) ranged from $<3$ to $2.1 \times 10^{4}$ with a mean value of $4.86 \times 10^{2} \pm 4.21 \times 10^{2} / \mathrm{g}$ in the examined kareish cheese samples. $68 \%$ of the sample contained $<3$ Escherichia coli/g (Table 3).

Nearly similar results for incidence were reported by Aman (1994); EL-Kholy, et al., (1995), but higher incidence was reported by Ahmed, et al., (1987); Nazem (1991) while lower incidence was reported by Halawa and ElMossalami (1998). Similar results for count were reported by Ahmed, et al., (1987); Bahout and Moustafa (2006)

Five main types of Escherichia coli have been associated with food borne diseases. The first, enterotoxigenic Escherichia coli which produce heat labile toxin type I is implicated in most cases of foodborne outbreaks Mayer, et al., (1991) and causes traveler's diarrhoea in human especially during visits to warmer countries (Hau, et al., (1998). The second, enteropathogenic Escherichia coli which causes infantile gastroenteritis associated with fever and bloody diarrhoea (Hoeprich, et al., (1994). The third, enterohemorrhagic Escherichia coli, which is responsible for hemorrhagic colitis and haemolytic uraemic syndrome (Griffin, 1991). The fourth, enteroinvasive Escherichia coli, which produces an illness very similar to dysentery. The last type, enteroaggregative Escherichia coli which has been implicated as a cause of prolonged diarrhoea in developing countries (Troller, 1993). Moreover the organisms were found to be responsible for cases of gastroenteritis, cystitis, pylitis, pyelonephritis as well as appendicitis and peritonitis Pyatki(1967); Marier, et al., (1973); Singh and Ranganattan (1974); Mossel (1975).

The most important serogroups among EHEC are $\mathrm{O}_{26}, \mathrm{O}_{111}, \mathrm{O}_{157}$ and of which $\mathrm{O}_{157}: \mathrm{H} 7$ being the most relevant serotype in food borne outbreaks Gonzalez (2002).

Regarding to E.coli isolated from the examined samples and as recorded in Table (5): 
$5(31.25 \%)$ out of 16 isolates were untypable, and the remaining isolates $11(68.75 \%)$ were serologically typed as follows $4(25 \%)$ O111, $3(18.75 \%) \mathrm{O}_{8}, 3(18.75 \%) \mathrm{O}_{125}$ and $1(6.25 \%) \mathrm{O}_{29}$. similar results were recoded by Gomez, et al., (2002); Gonzalez and Blanco (1989) recorded that $\mathrm{E}$. Coli untypable for $\mathrm{O}$ antingen represented $47 \%$, of the verotoxigenic strains , Moussa, et al., ( 2005) isolated 8 strains of E. Coli from milk samples, $3(37.5 \%)$ of them were $\mathrm{O}_{111}$.

The results recorded in Table (6) revealed that out of 16 E. Coli strains $6(37.5 \%)$ were enterotoxgenic, similar results were recorded by Krogh (1983); Poh1, et al., (1989).

The results tabulated in Table (7) showed that Enterotoxigenic strains isolated from kareish Cheese were highly resistant to Chloramphenicol, and Amoxicillin, Moderately resistant to and Doxycyclinne and senstive to Ceftiofur, Lincomycin + Spectinomycin, Norflooxacin and Gentamycin. These results nearly resemble that recorded by Ahmed, et al., (1994); Mellata, et al., (1998).

The results in Table (2) proved that Staphy lococcus aureus could be isolated from 12(24\%) of the samples with a range of $<100$ to $1.1 \times 10^{7}$ and a mean count of $4.84 \times 10^{5} \pm 2.91 \times 10^{5} / \mathrm{g}$ of the examined kareish cheese samples. $84 \%$ of the examined samples contained $<10^{2}-<10^{3}$ Staphylococcus aureus/g (Table 4). Similar results were reported by Araujo, et al., (2002); Bahout and Moustafa (2006), while higher values were reported by Ahmed (1980); de Almeida and Nader(2001).

The presence and growth of Staphylococcus aureus in dairy products is a potential public health hazard ICSMF (1978) since many strains of Staphylococcus aureus under favourable environmental conditions have the ability togrow and multiply with the production of thermostable enterotoxins, which cause food intoxication within 2-4 hrs after consumption of contaminated food Newsome (1988).

The enterotoxins of S.aureus are antigenically different types and include (A,B, $\mathrm{C}_{1}, \mathrm{C}_{2}, \mathrm{E}$ and TST "Toxic Shock Toxin") All these types of enterotoxins except TST were involved in foodborne illness. On the other hand, postpasteurization of the toxin contaminated milk as well as dairy products will not make it safe for consumption Robinson (1990).

Among the reasons of food examination for Staphylococcus aureus are to confirm that these organisms may be the causative agent of food borne illness, to determine whether the product is the potential source of Staphylococcus aureus food poisoning and to demonstrate postprocessing contamination, which mainly due to defect in the personal hygiene or exposure the food to inadequately sanitized food processing surfaces.

Staphylococcus aureus are wide spread in nature and it is a good indicator of the personal hygiene especially the workers with respiratory infections and suppuration Harvey and Gilmour (1990); Kamat, et al., (1991). Also inadequately cleaned utensils or equipment may also be a source of contamination.

Hence, presence of large number of Staphylococcus aureus in the product is considered a good indication that sanitation and temperature control have somewhere been inadequate ICMSF (1980).

The coordinator of the French surveillance system revealed that 69 documented outbreaks for milk and milk products were confirmed as the vehicle by the isolation of the etiologic agent. The food vehicles were distributed as follows: milk, $10 \%$; cheese, $87 \%$; others, $3 \%$. S. aureus was by far the most frequent pathogen associated with $85.5 \%$ of the outbreaks, De Buyser, et al., (2001).

Inspection of Table (2) revealed that Enterococci could be detected in $46(92 \%)$ of the samples with a range from $<100$ to $5.5 \times 10^{7}$, and a mean count of $3.74 \times 10^{6} \pm 1.55 \times 10^{6} / \mathrm{g}$ of the examined kareish cheese samples. The highest frequency distribution $(38 \%)$ lies within the range from $10^{2}-<10^{4}$ Enterococci/g (Table 4). Similar results for incidence were reported by Ahmed, et al., (1987); Aman (1994), but higher results were reported by Mahmoud (1993) and Bahout and Moustafa (2006). Also similar results for counts were reported by El-Barbary (1992); Bahout and Moustafa(2006), while lower values were reported by Ahmed, et al., (1987) and higher values were reported by Mahmoud (1993); Aman (1994).

Enterococci being normal inhabitants in alimentary tract of both man and animals, thus their presence in milk and its products is considered a definite index of faecal contamination Brooks (1974); ICMSF (1982), also they are found in the soil, on plants and in the intestine of the insects and birds Gelsomino, et al., (2002). Enterococci being comparatively heat resistant, salt tolerant and can grow at wide range of temperature, low $\mathrm{pH}$ and more resistant to drying, detergents, freezing and disinfectants. 
Enterococci may help in assessing the hygiene in factories Slanetz, et al., (1983); Colman and Ball (1984); Rao, et al., (1986); Harrigan (1998).Therefore, they are frequently responsible for producing unfavourable changes as bitterness, proteolysis and other defects in milk products Harrigan and Micance, (1966). They are widely distributed in nature and gain entry into milk and milk products through the contaminated water supply, equipment and unhygienic conditions of production and handling. They have been incriminated as direct or indirect cause of disease and food poisoning because of their ability to produce extracellular toxic metabolites Garg and Mital, (1991); Roushdy, et al., (1998).

The obtained high values of enterococci reflect the poor sanitary practices during manufacturing, handling, storage and distribution and the high numbers may at time constitute a public health hazard and may induce food poisoning

Bacillus cereus. The results in Table (2) showed that Bacillus cereus could be isolated from $25(50 \%)$ of the samples with a range of $<100$ to $9.1 \times 10^{5}$ and a mean count of $7.08 \times 10^{4} \pm 2.61 \times 10^{4} / \mathrm{g}$ from the examined kareish cheese samples. Most of samples $(58 \%)$ of the examined samples contained $<10^{2}-<10^{3}$ Bacillus cereus /g (Table 4). Nearly similar results were reported by Halawa and Moawad (1999); Bahout and Moustafa(2006)

Bacillus cereus is a food poisoning microorganism, produces one emesis-causing toxin and three enterotoxins that elicit diarrhea. There are two types of food poisoning syndromes caused by B. cereus. The first was diarrhoeal type syndrome while the second was vomiting type Ehling-schulz, et al., (2004). It has been recognized that high number of $\mathrm{B}$. cereus ranged from $10^{6}-10^{8} / \mathrm{ml}$ is needed to elicit symptoms of food poisoning, Mossel, (1982). However, in compromised consumers a much smaller dose of $1.2 \times 10^{3} / \mathrm{ml}$ may cause illness, Gianella and Brasilla, (1979). Neither two forms of illness should be considered life-threating to normal healthy individual.

The contamination of milk and milk products by such organisms may be attributed to the fact that $\mathrm{B}$. cereus is widely distributed in nature and usually contaminate milk during milking or storage on the farm, then gain entrance to dairy products from which they are prepared. However, the extent of B. cereus contamination depends on the effectiveness of hygienic measures applied during processing, handling and distribution of milk products.

Inspection of Table (2) revealed that Clostridium perfringens could be detected in $3(6 \%)$ with a range from $<100$ to $3.6 \times 10^{3}$, and a mean count of $9.5 \times 10^{1} \pm 7.37 \times 10^{1} / \mathrm{g}$ of the examined kareish cheese samples. The highest frequency distribution $47(94 \%)$ was in the range $<10^{2}$ Clostridium perfringens /g (Table 4). Higher results reported by Amer, et al., (1996); Bahout and Moustafa (2006)

Clostridium perfringens is a classical agent of food-borne disease but because of the mildness and self-limiting nature of the illness, many cases are undiagnosed Sanz, et al., (2002).

The results in Table (8) showed that Yersinia enterocolitica could be isolated from $1(2 \%)$ out of the examined samples. Similar results were obtained by Abdel Hady (1993), however lower results were recorded by Northolt (1983). The lower incidence of Yersinia enterocolitica in cheese samples can be attributed to the high contamination of the cheese with other competitors and the difficulty in detection of small numbers of Yersinia enterocolitica among large numbers, Bottone (1977).

Yersinia enterocolitica is considered a causative agent of gastroenteritis, Morse, et al., (1984), arthritis, Archer (1985) and pseudoappendicular syndrome, deGroote, et al., (1982); Cover and Aber (1989).

A Norwegian study of 458 hospitalized patients over 10 years indicates that acute and chronic disease of the liver, pancreas and gastrointestinal tract can result from Yersiniosis, Saebo and Lassen( 1991, 1992a,b,c). On the other hand Yersinia enterocolitica could be isolated from 73/333 (21.9\%) of patients, mostly women over 50 years with erythema nodosum (Winblad, 1975).

Salmonella and Shigella could not be detected in any of the examined samples. Similar results were reported by De Centorbi, et al., (1989); El-Kholy(1989); Maifreni, et al., (1993); Windrantz and Arias (2000).while higher results were reported by Wouafo, et al., (1996); Kruy, et al., (2001). Therefore, to safeguard the consumer from being infected and to save the products from contamination the following suggestions are to be considered. Educational programs should be imposed for producers and handlers. Production, handling and distribution should be done under strict hygienic measures. Continuous refrigeration of milk from time of milking till used in manufacturing of Kareish cheese. 
Prevention of recontamination of manufactured Kareish cheese. The consumers should take in consideration the cleanliness of sales persons. Efficient cleaning of all utensils and equipment. Timely notification of food borne diseases must be encouraged. The final retail containers used are preferred to be dispensable and efficiently closed or covered.

\section{References}

Abd-El-Hady, H. M. (1993): Studies on Campylobacter jejuni and Yersinia enterocolitica, as food-posisoning causative organisms in milk and some dairy products. Ph.D. Thesis, Fac. Vet. Med., Cairo Univ. Egypt.

Abd-El-Shaheed, Y. S. (1996): Enterococci in some locally manufactured dairy products. M.V. Sc. Thesis, Fac. Vet. Med., Alex.Uni. Egypt.

Ahmed, A. A-H. (1980): Studies on the enterotoxigencity of Staph. aureus isolated from milk and milk products . Ph. D. Thesis, Fac. Vet. Med. Assiut Uni., Egypt.

Ahmed, A. A-H.; Moustafa, M. K. and Abd-El-Hkiem, E. H. (1987): Sanitary condition of kareish cheese manufactured in Assiut city. Assiut Vet. Med. J., 19 (37) : $75-80$.

Ahmed, I.; Yadavaj, N. S. and Ahmed, S. (1994): High level transferable resistance among E.coli.. Ind. J. Anim Sci., 64(5)439-445.

Aly, S. A.; Farag, D. M. and Galal, E. A. (2007): Effect of Gamma irradiation on the quality of kareish cheese. Assiut Vet. Med.J., 53 (113):76-87.

Aman, I. M. (1994): Microbiological quality of kareish cheese in Kafr EL-Sheik city. Assiut Vet. Med. J., 31:182189.

Amer, I. H., Bahout, A. A. and Hatab, M. E. (1996): Prevalence of Clostridium perfringens in milk and dairy products. The proceeding of $3^{\text {rd }}$ Vet. Med. Cong., 8-10 October, Fac. Vet. Med., Zagazig Univ., pp203-208.

A.P.H.A.; American Public Health Association(1992): Standard methods for the examination of dairy products. $16^{\text {th }}$ ed, American public Health Association New York. Araujo, V. S.; Pagliares, V. A.; Queiroz, M. L. and Freitas-Almeida, A. C.(2002): Occurrence of Staphylococcus and enteropathogens in soft cheese commercialized in the city of Rio de Janeiro, Brazil. J. Appl. Microbiol., 92(6):1172-1177.

Archer, D. K. (1985): Enteric microorganisms in rheumatoid diseases : Causative agents and possible mechanisms, J. Food Prot., 48:538-45.

Bahout, A. A. and Moustafa, A. H. (2006): Occurrence of some pathogenic microorganisms in relation to public health in kareish cheese. Assuit Vet. Med.J., 52 (111): 8592.

Bottone, E. L. (1977): Yersinia enterocolitica: Apanoramic view of a charismatic miccroorganism, CRC Critic. Rev. Microbiol., 5:211-241.

Brooks, D. E. J. (1974): Enterococci as faecal indicators in dairy products xix Int. D. Congress. India, IE, 377-378. Dairy Sci. Abst., 36: 2775.

Collee, J. G.; Fraser, A. G.; Marmio, B. P. and Simmons, A. (1996): Practical medical microbiology $14^{\text {th }}$ ed.Charchilu livingstone ,New York, E din Eurgh,London, Madrid Melbourne, Sanfrancisco and Tokyo.

Colman, G. and Ball, C.C. (1984): Identification of Streptococci in medical laboratory. J. Applied Bact., 57:14.
Cover, T. I. and Aber, R. C. (1989): Yersinia enterocolitica, New England J. Med., 321:16-24.

De Almeida Filho, E. and Nader Filho, A. (2001): Occurrence of Staphylococcus aureus in frescal type cheese. Int. J. Food Microbiol., 20;67(1-2):1-17.

De Buyser, M. L.; Dufour, B.; Maire, M. and Lafarge, V.(2001): Implication of milk and milk products in foodborne diseases in France and in different industrialised countries. Int. J. Food Microbiol., 20;67(1-2)1-17.

De Centorbi, O. P.; de Guzman, A. C.; de Cuadrado, A. A.; Laciar, A. L.; Alcaraz, L. E.; de Milan, M. C. and de Pederiva, N. B. (1989): Determination of the sanitary quality and detection of Salmonella $\mathrm{spp}$ and Yersinia enterocolitica in ice cream. Rev. Argent Microbiol., 21(2):63-9.

De Groote, G.; Vandepitte, J. and Wauters, G. (1982): J. Infect., 189-197. Cited in Doyle (1989).

Djuretic, T., Wall , P. G. and Nichols, G. (1997): General outbreaks of infectious intestinal disease associated with milk and dairy products in England and Wales :1992-1996. Common Disrep Rev.1997 Mar7:7(3):R41-5 . Dairy Sci. Abst., 60(6)447(1998).

Ehling-Schluz, M., Fricker, M. and Scherer, S. (2004): Bacillus cereus, the causative agent of an emetic type of food-borne illness. Mol. Nutr. Food Res., 48(7) 497-87.

El-Barbary, M. (1992): Occurrence of enteric microorganisms in some dairy products in Sharkia governorate. A thesis for the degree of master, Fac. of Vet. Med. Zgazig Uni., Egypt

El-Kholy, A. M., Hafez, R. S., and Mahmoud, M.D. (1995): Occurrence of some food poisoning bacteria in Egyptian food cheese. Bani-Suef Vet. Med. Res., 7 (10) 342-355.

El-Kholy, A. M. (1989): Enterobacteriaceae in Egyptian food cheese and their public health significance. Assiut Vet. Med. J., 21(42)70-75.

El-Leboudy, A., A. (1989): Potential food poisoning organisms in some dairy products at consumer level. Ph.D. Thesis, Fac. Vet. Med., Alex. Uni.Egypt.

El-Mossalami, H. (1999): Occurrence of faecal Coliforms and Enteropathogenic Escherichia coli in soft cheese in Alex. . M. V. Sc. thesis, Fac. Vet. Med. Alex. Univ.Egypt.

Garg, S. K. and Mital, B. K. (1991): Enterococci in milk and milk products. Critical Rev. Microbiol., 18(1)15-45.

Gelsomino, R.; Vancanneyt, M.; Cogan, T. M.; Condon, S. and Swings, J. (2002): Source of enterococci in a farmhouse raw-milk cheese. Appl Environ Microbiol., 68(7)3560-5.

Gianella, A. and Brasilla, L. (1979): A hospital foodborne outbreak of diarrhoea caused by Bacillus cereus. J. Infect. Dis., 139: 366-370.

Gomez, D.; Miliwebsky, E.; Fernandez, P. C.; Baschkier, A.; Manfredi, E.; Zotta, M.; Nario, F.; Piquin, A.; Sanz, M.; Etcheverria, A.; Padola, N.; Parma, A. and Rivas, M.(2002): Rev. Argent Microbiol., 34(2)66-71.

Gonzalez, E. and Blanco, J.(1989): Serotypes and antibiotics resistance of Verotoxigenic (VTEC)and Necrotizing (NTEC) E.coli strains isolated from calves with diarrhea .Fems. Microbiology Letters 60(1)31-36.

Gonzalez, Garcia, E,A.(2002): Animal health and foodborne pathogens: enterohaemorrhagic O157:H7 strains and other pathogenic Escherichia coli virotypes (EPEC, ETEC, EIEC, EHEC . Pol. J. Vet. Sci., 5(2)103-15.

Griffin, P. M. (1991): The epidemiology of infectious caused by Escherichia coli O157:H7 other 
enterohaemorrhagic Escherichia coli and the associated haemolytic uraemic syndrome. Epidemiol.Rev., 13:60-98.

Guarino, A.; Capano, G. and Malamisura, B.(1987): Production of E.coi Sta-like heat stable enterotoxin by Citrobacter frundii from humans. J. Clin. Microbiol., 25(1):110-114.

Halawa, M. A. and El-Mosalami, M. K. (1998): Fluorocult medium for direct detection of Escherichia coli in some dairy and meat products. Alex. J. Vet. Sci., 14(3)43-51.

Halawa, M. A. and Moawad, A. A. (1999): Bacterilogical quality of street-vended white cheese. Alex. J. Vet. Sci., 15(4)855-864.

Harrigan, W. F. (1998): Laboratory methods in food microbiology. $3^{\text {rd }}$ ed. Academic Press Sa Diego, California, USA.

Harrigan, W. F. and Micance, M. G. (1966): Laboratory methods in microbiology. Academic Press, London and New York.

Harvey, J. and Gilmour, A. (1990): Isolation and identification of Staphylococci from milk powders produced in Northern Ireland. J. Appl. Bacteriol., 68:433438.

Hau, Y. T.; Liang, J. and Wan, R. C. (1998): Use of multiplex PCR system for the simultaneous detection of heat labile and heat stable toxin. II. Genes of enterotoxigenic Escherichia coli in skim milk and porcine stool. J. Food Prot., 61(2)141-145.

Hoeprich, P. D.; Jordan, M. C. and Ronald, A. R. (1994): Infectious Disease: A Treatise of Infectious Processes. $5^{\text {th }}$ ed. Philadelphia: J.B.Lippincott CO. pp. 7281194.

I.C.M.S.F.;International Committee on Microbiological Specification for Food (1978): Microorganisms in foods. I. Their significance and methods of enumeration. $2^{\text {nd }}$ ed. University of Toronto Press, Toronto, Buffalo and London.

I.C.M.S.F.;International Committee on Microbiological Specification for Food (1980): Microorganisms in foods. A. Effect of processing on microorganisms. 1-Further contamination P.419. Microbial Ecology of Food. Vol. IIFood Commodities Academic Press. Toronto Press, Toronto, Buffalo and London.

I.C.M.S.F.; International Committee on Microbiological Specification for Food (1982): Microorganisms in foods. I. Their significance and methods of enumeration. $2^{\text {nd }}$ ed. University of Toronto Press, Toronto, Buffalo and London. Kamat, M. Y.; Sulebele, G. and Nirupama, Sabanis (1991): A comparative evaluation of media for enumeration of Enterotoxigenic Staphylococci by selective enrichment technique. J.Food Sci.Technol.,India, 28(6)381-383.

Khair Allah, H. M. (2000): Safety and quality of some dairy products through microbial criteria. M. V. Sc. Thesis, Fac .Vet. Med., Alex. Uni., Egypt.

Koneman, E. W.; Allen, S. D.; Jan, W. M.; Schrechn, Berrjer, P. C. and Winn, T. R.(1992): Colour atlas and textbook of diagnostic Microbiology $4^{\text {th }}$ ed. J.B.Lippinctt Co. Philadelphia U.S.A.

Krogh, H. V. (1983): Occurrence of Enterotoxigenic E.coli in calves with acute neonatal diarrhoea. Nord. Vet. Med., 35(10)346-352.

Kruy, S. L.; Soares, J. L.; Ping, S. and Sainte-Marie, F. F. (2001): Microbiological quality of "ice, ice cream. Sorbet" sold on the streets of Phnom Penh; April 1996April 1997. Bull Soc Pathol Exot., 94(5):411-414.

Mahmoud, M.D. (1993): Prevalence of food poisoning organisms in some dairy products in Bani-Suef Governorate
M.V. Sc. Thesis . Fac. Vet. Med., Bani-Suef, Cairo Univ. Egypt.

Maifreni, M.; Civilini, M.; Domenis, C.; Manzano, M.; Di Prima, R. and Comi, G.(1993): Microbiological quality of artisanal ice cream. Zentralbl Hyg Umweltmed 194(56)553-70.

Marier, J. G.; Swanson, R. C.; Callahan, W. and Mehlman, I. J. (1973): An outbreak of enteropathogenic Escherichia colifood borne disease traced to imported French cheese. Lancet 2 (7842):1376-1378. Dairy Sci. Abst., 36(7):353.

Mayer, R.; Luthy, J. and Candrian, U. (1991): Direct detection by polymerase chain reaction (PCR)of Escherichia coli in water and soft cheese and identification of enterotoxigenic strains. Letters Appl. Microbiol., 13:268271.

Mellata, M.; Jacquemin, E.; Bakour, R. and Mainil, J. (1998): Antibiotic resistance of E.coli strains of bovine and avian origin isolated in Algeria. Ann..Med.Vet., 142(2): 129-138.

Morse, D. L.; Shayegani, M. and Gallo, R. J. (1984): Epidemiologic investigation of aYersinia Camp. Outbreak linked to a food handler. American journal of Public Health, 74: (6) 589-592.

Mossel, A. A. (1975): Microbiology of food and dairy products. Fac. Vet. Med. Utrecht. Univ.

Mossel, D.A.A. (1982): Microbiology of Food. $3^{\text {rd }}$ ed. The Univ. Utrecht, The Netherlands ISBN.

Moussa, I. M.; Ghoneim, M. A. and Ibrahim, A. K. (2005): Rapid detection and characterization of Shigatoxigenic E.coli (STEC) in bovine faecal and milk samples by multiplex PCR assays. J. Egypt. Vet. Med. Assoc., 65(1)19-34.

Nawar, D. M. (2001): Hygienic quality of some street vended dairy products. Thesis for the degree of M.V.Sc. Fac. Vet. Med. Alexandria Univ., Egypt.

Nazem, A. M. (1991): Assessment of the hygienic quality of some dairy products. Ph D.Thesis ,Fac. Vet . Med. Alex. Univ., Egypt.

NewSome, R. I. (1988): Staph. aureus. Food Tecnol.,42 940:194.

Northolt, M. D. (1983):Pathogenic micro-organisms in fermented dairy product. Netherlands Milk and Dairy J., 37(4):247-248.

Pohl, P.; Lintevnmans, P.; Muylem, K.; Van Kaeckenbeek, A. and Mainil, J. (1989): Characterization of 21 strains of E.coli $\mathrm{O} 157$ isolates from calves and goat. Annal. Med. Vet., 133(8)673-680.

Pyatki, K. (1967): Microbiology MIR Publ. Moscow, USSR.

Rao, C. U. M.; Shankar, P. A. and Laximinaryana, H. (1986): A study of Enterococci occurring in milk and milk products. Indian J. Dairy Sci., 39(3)281-285.

Robinson, R. K. (1990): Dairy Microbiology. I- The microbiology of milk applied, The microbiology of milk products. $2^{\text {nd }}$ ed., Elsevier Applied Sci. Publ, London and New York.

Roushdy, I. M.; Ehrmann, M. A. and Vogel, R. F. (1998): Molecular identification and characterization of halo-tolerant lactic acid bacteria isolated from soft pickled Damietta cheese. Adv. Food Sci., 20(1/2)40-45.

Saebo, A, and Lassen, J. (1991): New observations on acute and chronic disease associated with Yersinia enterocolitica infection. Contributions Microbiol. Immunol., 12:272-277

Saebo, A. and Laassen, J. (1992a): Acute and chronic 
liver disease associated with Yersinia enterocolitica infection: a Norwegian 10 - year follow-up study of 458 hospitalized patients. J. Int. Med., 231:531-535.

Saebo, A. and Lassen, J. (1992b): Acute and chronIc pancreatic disease associated with Yersinia enterocolitica infection a Norwegain 10-year follw-up study of 458 hospitalized patients. J. Int. Med., 231:537-41.

Saebo, A. and Lassen, J. (1992c): Acute and chronic gastointestinal manifestations associated with Yersinia enterocolitica infection a Norwegian 10-year follow-up study of 458 hospitialized patients, Ann. Surg., 215:250255.

Saleh, O. A. (1989): Enterobacteriaceae in some dairy products. M.V.Sc. Thesis, Fac. Vet. Med., Alex. Uni.Egypt.

Sanz, J. C.; Dominguez, M. F.; Sagues, M. J.; Fernandez, M.; Feito, R.; Noguerales, R.; Asensio, A. and Fernandez, De La H. K.(2002): Diagnosis and epidemiological investigation of an outbreak of Clostridium perfringens food poisoning. : Enferm Infec Microbiol Clin., 20(3):117-22.

Sarantinopoulos, P.; Kalantzopoulos, G. and Tsakalidou, E. (2002): Effect of Enterococcus faecium on microbiological, physicochemical and sensory characteristics of Greek Feta cheese. Int J Food Microbiol .,
5:76(1-2)93-105.

Singh, R. S. and Ranganathan, B. (1974): Occurrence of enteropathogenic Escherichia coli serotypes in milk and milk products. Milchwissenschaft, 29:529.

Slanetz, J. A.; Barento, R. and Ingio, B. (1983): Contribution to study of Mahon cheese III Lactic acid bacteria and Enterococci. Food Sci. Tech., 16(8):1807.

Troller, J. A. (1993): Sanitation in Food Processing. $2^{\text {nd }}$ ed. New York, London. Academic Press, pp. 98-129.

Van Netten, P.; VanDe Moosdijk A.V.; Hoensd, P.; Mossel, D. A. and Perales, I. (1990): Psychrotrophic strains of B.cereus producing enterotoxin. J. Appl. Bacteriol., 69( 1):73-79.

Wienke, A. A.; Roberts, D. and Gilbert, R. J. (1993): Staphylococcal food poisoning in the United Kingdom ,1969-1990. Epidemiol. Enfect., 110 (3):519-531.

Winblad, S. (1975): Scand. J.Infect. Dis. 7:191-195.

Windrantz, P. and Arias, M. L. (2000): Evaluation of the bacteriological quality of ice cream sold at San Jose, Costa Rica. Arch Latinoam Nutr., 50(3):301-303.

Wouafo, M. N.; Njine, T. and Tailliez, R.(1996): Hygiene and microbiologic quality of ice creams produced in Cameroon. A public health problem. Bull Soc Pathol Exot., 89(5):358-362.

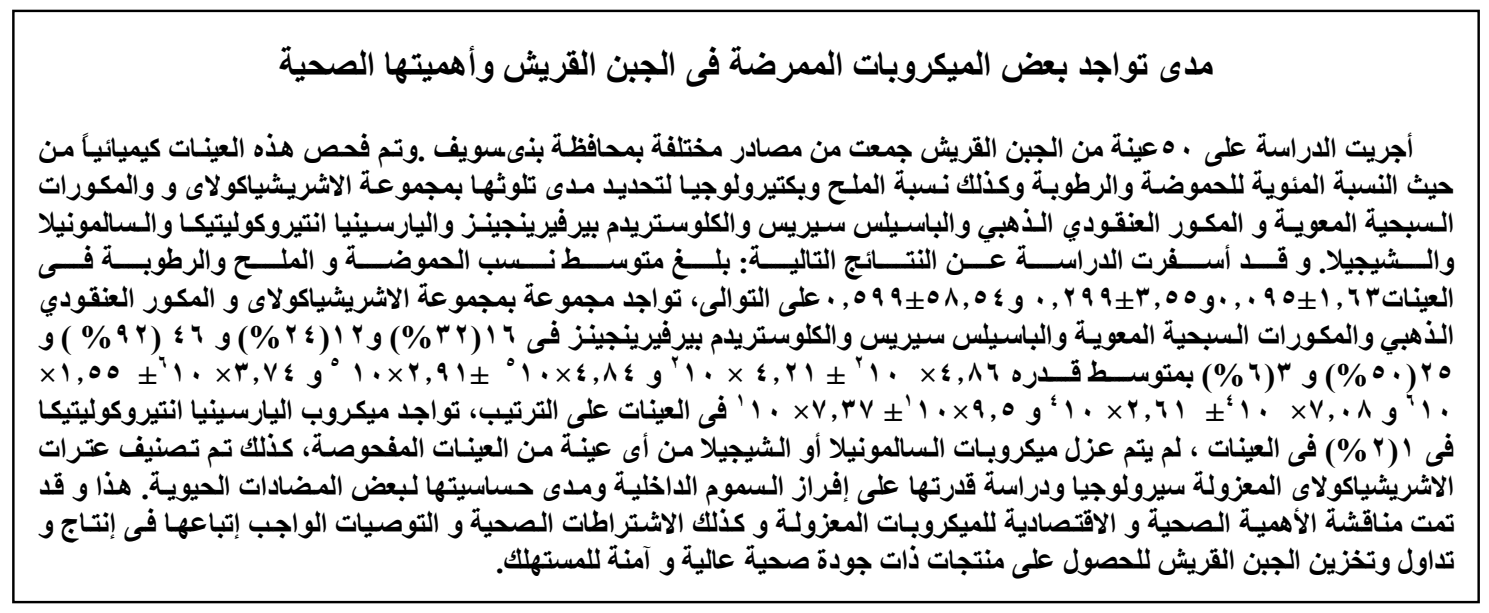


